Article

\title{
Scientific and Ethical Issues in Exporting Welfare Findings to Different Animal Subpopulations: The Case of Semi-Captive Elephants Involved in Animal-Visitor Interactions (AVI) in South Africa
}

\author{
Barbara de Mori ${ }^{1,2}$, Elena Stagni ${ }^{2,3}$, Linda Ferrante ${ }^{1,2} \oplus$, Gregory Vogt ${ }^{2,4}$, Keith A. Ramsay 5 \\ and Simona Normando $1,2, *$ (D) \\ 1 Department of Comparative Biomedicine and Food Science, Università degli Studi di Padova, viale \\ dell’Università 16, Agripolis, 35020 Legnaro PD, Italy; barbara.demori@unipd.it (B.d.M.); \\ linda.ferrante@phd.unipd.it (L.F.) \\ 2 Ethics Laboratory for Veterinary Medicine, Conservation, and Animal Welfare, Università degli Studi di \\ Padova, viale dell’Università 16, Agripolis, 35020 Legnaro PD, Italy; estagni.res@gmail.com (E.S.); \\ greg@conservationguardians.co.za (G.V.) \\ 3 Independent researcher, Via Ranzani, 17, 40127 Bologna, Italy \\ 4 Conservation Guardians, Shongweni Nature Reserve, Outer West, 3610 Kwa Zulu Natal, South Africa \\ 5 Department of Agriculture Forestry and Fisheries, South Africa-former Scientific Manager, Animal \\ Production, 20 Steve Biko former (Beatrix) Street, Agriculture Place, Arcadia 0031, Pretoria, South Africa; \\ keithrms9@gmail.com \\ * Correspondence: simona.normando@unipd.it; Tel.: +39-049-641-231
}

Received: 3 September 2019; Accepted: 15 October 2019; Published: 19 October 2019

Simple Summary: In southern Africa, several elephants are involved in 'wildlife tourism interactions' with tourists, whose acceptability is the focus of much media interest. It is important that the welfare of the animals involved in such activities is monitored in order to grant them an acceptable quality of life. Until now, protocols to assess welfare in African elephants have been developed only for zoo elephants. However, protocols developed for a different situation may not be suitable for these elephants, which live under different circumstances (for example, in some cases they tend to be able to roam free in the bush for a part of the day and to be allowed contact without protective barriers with people). We discuss the possible problem of extending findings found in zoo elephants to elephants involved in activities with tourists outside the zoos. This concern was also highlighted by elephant experts who said that in $23.6 \%$ of cases the main welfare problems of zoos' elephants were different from those of elephants involved in interactions with tourists in South Africa. Moreover, their agreement was low when they were asked the acceptability of some procedures, which are often applied differently in zoos and in the facilities offering interactions with tourists.

Abstract: Elephants are charismatic, cognitively highly-developed animals, whose management
conditions can vary along a "wild-captive continuum." Several protocols have been proposed for
the assessment of zoo elephants' welfare. It is important to investigate the possible limitations,
if any, of extending findings from zoo elephants to conspecifics in a different dynamic in said
"wild-captive continuum." In this paper, findings regarding two issues will be discussed: those
regarding the external validity and those regarding the acceptability of management procedures
as applied to semi-captive (i.e., able to roam freely for part of the day) elephants involved in
visitor-interaction programs in South Africa. In a questionnaire-based survey, half of the responding
experts stated that at least some of the welfare issues they ranked as the five most important in captive
elephants' management had a different relevance for semi-captive individuals, resulting in $23.6 \%$
of the issues being rated differently. Moreover, there was no agreement among the experts on the
ethical acceptability of any of the investigated procedures used in the management of semi-captive 
elephants involved in visitor-interaction programs. Caution is thus needed when exporting findings from one subpopulation of animals to another kept in different conditions and more scientific and ethical research is needed on the topic.

Keywords: animal welfare; elephants; ethics; external validity; assessment; animal-visitors interactions

\section{Introduction}

African elephants (Loxodonta africana) are highly charismatic animals, who have a rich social life [1-3] and complex cognitive abilities [4-9]. Therefore, it is not surprising that their welfare in captive conditions has been the focus of much scientific interest, such as that of primates [10-12]. Like primates, elephants under human care can be described as being distributed on a "wild-captive continuum" in different situations, as outlined by Hosey [13] for primates. However, most of the research on elephant welfare has been done on zoo animals. Hence it is important to reflect on the possible risks of transferring findings from zoo animals to elephants on a different position in the "wild-captive continuum." The risk of underestimating existing differences in the range of management options is high. Animal welfare is highly influenced by the context in which animals are housed and by choices about how to manage them: different management methods in the "wild-captive continuum" involve not only different housing conditions, but also different stakeholders and different values. An example can be the so-called "semi-captive" elephants housed in facilities that offer a range of interactions between the elephants and tourists in South Africa. It is worth noting that, while most of the scientific studies proposing methods/parameters to assess welfare include various reliability checks (e.g., concordance among different observers, and concordance between data taken some time apart), as reviewed by Williams et al. [14], for elephants, external validity is virtually always ignored. The same is true for a comparative study about ethical acceptability of management options.

This paper is part of a line of research aimed at studying subpopulations of wild animals which are involved in visitor-interaction programs both in zoos and other facilities offering such interactions, by merging a scientific and an ethical approach. Such subpopulations are managed in a way that is often slightly different from other captive subpopulations, if not for other reasons, at least for the fact that they are often asked to have a direct interaction with visitors in "free contact" conditions (see below). It is therefore important to analyze both the scientifically and the ethically relevant aspects of such differences, mainly because they can be relevant when assessing as well as when attempting to improve the welfare of these animals. The aim of this paper is to highlight potentially welfare-relevant differences between semi-captive visitor-interacting elephants in South Africa and zoo elephants in order to stimulate debate about the pros and cons of exporting welfare assessment methods from one subpopulation of a wild animal species to another kept in different conditions.

It is now widely accepted that science and ethics are inextricably intertwined facets of animal welfare's evaluation $[15,16]$. Ethics, together with economics and social sciences, plays a role both in the definition of animal welfare $[17,18]$ and in decisions about the minimum acceptable level of welfare to provide $[19,20]$ and dictates the acceptability of the animal's life conditions. Ethics, therefore, play a role in the designing of protocols addressing and evaluating welfare issues [21]. Ethics is also needed to assess specific, controversial welfare-relevant issues, which can vary depending on the animal population studied. In this study, we discuss both the issue of external validity per se and that of acceptability of management procedures that are typical of semi-captive animal-visitor interactions. 


\section{The "Semi-Captive" Elephants in South Africa}

Facilities offering interactions with animals belonging to wild species to tourists, similar to those in Thailand [22], are widespread in southern Africa. For example, in South Africa, around 120 elephants [23] are kept in facilities defined as captive facilities [24], but which fulfil the criteria we use to define semi-captive animals. These facilities are open to the public who pay a fee to enter them. The common ground of these facilities is that they offer some form of animal-visitor interaction with the elephants they house. The interactions offered by these captive elephant facilities range from attending training shows, to hand feeding, walking with, and even riding on the elephants. Usually, these interactions include forms of non-protected contact between people (both handlers and public) and elephants [25], whereas a policy of "protected contact" has long been recommended for western zoos [26]. In the protected contact system, human and animal spaces are separated; the elephants are managed using positive reinforcement training and punishment is not allowed. Trainers never attempt to socially dominate the elephants [27]. These facilities can be extremely different from one another in their organization and the way they function, and each facility represents a range of management dynamics. However, there are some common traits: Apart from being involved in interactions with people, as already mentioned, the animals kept in most of these facilities tend to be somewhat less space-restrained than zoo-housed elephants, at least for part of the day. For example, some of them live on large tracts of land and are lured by high-energy food rewards to come in for interactions. Others are stabled in pens and/or buildings and are herded to the bush for part of the non-show/interaction time. Once in the bush, the elephants are let free to choose what to do (which is usually foraging) and to move around, without any imposed activity, under the supervision of their handlers, unless there is some emergency prompting the handlers to intervene. This virtually non-restricted activity in the bush will be referred to as free choice activity, (FCA). The ability to explore and interact in a virtually non-restricted way with the natural environment is deemed to be an important, welfare relevant, cognitive stimulant for animals [28]. Clubb and Mason [29] describe the system of working Asian elephants-tamed and trained elephants not held in zoos-as extensive. The authors cite agricultural literature, which uses 'extensive' in contrast to 'intensive,' to indicate a less physical restraint [30]. The use of this term might be linked to the fact that during the night the Asian working elephants are allowed to move in forests, although hobbled, and to feed on natural vegetation [31]. Groups are large and mixed, and encounters with wild elephants are common [32]. It can be argued that the greater distances roamed, the possibility to select the food and to show more natural behaviors have a positive influence on the elephants in extensive or semi-captive conditions [33]. In the South African facilities, the elephants are generally confined into paddocks or stables during the night, but most have a certain degree of freedom during the day, being herded around the reserve for FCA for a variable time of the day. It is, therefore, reasonable to define them as semi-captive, or as extensively managed as Asian working elephants are, differences notwithstanding. It is important to note though, that whilst most of these elephants are indeed less restrained than their zoo counterparts, there could be exceptions. In some cases, they could be released only in a fenced area and called back to the stable for the night, or, sometimes when the "interaction with tourist" agenda is full, they could be allowed to roam for shorter periods of time in a paddock close to the stables.

It is, therefore, logical that when assessing the welfare of such elephants, one needs to address both their distinctive human-controlled general management and the specific issues related to the interactions with visitors. 


\section{The Issue of External Validity}

One of the main scientific issues in welfare evaluation is the overall quality and meaning of the parameters used in the assessment. Scientific evaluation relies on measurements that have to be reliable and valid [34]. "Reliability concerns the extent to which measurement is repeatable and consistent: that is, free from random errors." [34] (p. 72). "Validity concerns the extent to which a measurement actually measures what the investigator wishes to measure and provides information that is relevant to the question being asked." [34] (p. 73). Validity has often been a major source of concern, as the biological meaning of the measures is seldom known, and many parameters tend to be unspecific (e.g., changes can be elicited by both positive and negative arousing experiences [35]). Another important facet of validity, which can be important in animal welfare research, is that of "external validity," defined as the extent to which the results are applicable "to other situations (environmental contexts), population, or species" [36] (p. 124). This aspect is particularly relevant when considering the welfare of individuals of wild animal species under human management, because the different ways they are managed can be seen as being distributed on a "wild-captive continuum" among the different situations [13]. Therefore, the issue of the likelihood of the results obtained on animals in a certain situation being also valid for those in a different one on the "wild-captive" spectrum needs careful scientific consideration. On one hand, the possibility to apply the results (e.g., in terms of issues that need investigating the most, and of parameters used for assessment) gathered from animals housed and managed in one condition to those in different conditions, would save the costs of conducting ad hoc research for each condition of the continuum. On the other hand, in ethology, there is usually not such a thing as a "golden standard" to be used to assess a criterion's validity. Therefore, the risk of using measures that, although reliable, are not valid in the new condition is not to be underestimated.

Another important aspect of any measurement is its feasibility, that is, the practicality of the measure for use in the field [37], and feasibility is likely to be influenced by the management systems of the animals, as well. In order to give a basis to discuss external validity, a brief summary of the main welfare research on zoo African elephants will be given.

\section{Approaches to Zoo African Elephants' Welfare Assessment}

In 2002, Clubb and Mason [29] published the first comprehensive study on elephant welfare, highlighting the lack of agreement about the best practice and the absence of reference to welfare in the standards. Available data on elephant welfare indicators were collected through an extensive search of the literature and records of studbooks; communication with several organizations and scientists; and scientist's visits to facilities. Variables which were likely to influence the welfare (general husbandry, social aspects, handling and training, and source of the animal) and four groups of welfare indicators for which data exist for zoo elephants (overall mortality rates, causes of mortality and morbidity, and reproductive and behavioral problems, including stereotypies and aggression directed to conspecifics or humans) were included. Zoo elephants were compared to elephants kept in extensive system (Asian timber camps) and wild populations, finding that only mortality significantly varied among the data available for both conditions $[29,38]$.

In 2008, the final report of another comprehensive study was published by Harris et al. [33]. Opinions from an elephant welfare expert panel on the most important welfare indicators and factors of zoo/safari park elephants were gathered, and variables to collect data directly in the zoos were selected. The experts included zoo curators and managers, zoo elephant keepers, zoo vets, zoo inspectors, biologists, and behavior and welfare scientists. Data on husbandry, behavior (e.g., eating, drinking, social behavior, sleeping, excessive aggression, and stereotypies), health (especially musculoskeletal system: foot health score and locomotion score), a body condition score, and fecal cortisol metabolites were collected in 13 UK zoos and wildlife parks. Elephant history, keeper and health check questionnaires, and sheets for house and paddock descriptions were also used. The prevalence of health and behavioral indicators of poor welfare was described and it was possible to correlate space allowance with stereotypes and gait. 
These studies notwithstanding, in 2010, Kreger and Hutchins [39] still noted that welfare guidelines for elephant management in zoos were mainly based on experience and not on scientific data and that they somewhat disagreed.

In 2013, Carlstead et al. [40] presented a project, which used an epidemiological approach to correlate the prevalence of positive and negative welfare states with the environmental, management, and husbandry factors that affect the welfare of zoo elephants. The animal-based indicators identified referred to behavior (e.g., walking distances, stereotypies, and laying behavior [41-43]), physiology (serum progesterone and prolactin [44]), and health (e.g., body condition score, abnormalities in the musculoskeletal system of the limbs, and foot physical examination $[45,46])$, and were based on seven animal-based criteria among the twelve in the Welfare Quality Protocol. The data were collected with different methods in American Zoo Association accredited Zoos: directly by on-site zoo personnel, retrospectively, and through surveys for experienced staff members. The results of the research project were published in 2016-2017 [41-51].

In 2015, a study commissioned by the Department of Environment, Food Rural Affairs (DEFRA), focused on the behavioral indicators as part of a wider set of indicators to assess the welfare of elephants in UK zoos [52]. Behavioral indicators and resources were identified through a literature review and focus group teleconferences with stakeholders, and were reviewed with the project's External Advisory Panel. The 25 stakeholders included keepers, curators/managers, veterinarians, and zoo-based researchers working in 12 Ireland/UK zoos and 11 other, independent worldwide researchers studying captive and/or wild elephants' behaviors. The panel selected 76 behavioral measures and grouped them into twelve categories (social interactions, abnormal behavior, arousal behavior, qualitative assessment, behavior occurring under stress, vocalizations, cognitive measures, environmental interactions, facial expressions, species-appropriate behaviors/activity budgets, defense behaviors, and comfort behavior/self-maintenance). The prototype tool consisted of three sections, the qualitative behavioral assessment, daytime behavior questions, and nigh-time behavior questions, and was designed to take no longer than $30 \mathrm{~min}$ to complete. A reliability, validity (i.e., inter-rater reliability and test re-test reliability, internal consistency, face validity, and construct validity testing predictions) and feasibility trial, conducted in three UK zoos, led to a further selection of the behavioral measures to be included in the tool. Further trials investigating reliability and validity lead to the development of a final evidence-based welfare assessment tool for zoo elephants, whose items had been selected based on their accuracy, validity, feasibility, and practicality of use by elephant keepers [53]. Using the same methodology, another project's part provided evidence suggesting changes in the Secretary of State Standard Modern Zoo Practice guidelines for elephants [52].

\section{Dedicated Protocols for Semi-Captive Elephants' Welfare Assessment in South African Facilities Addressing the External Validity and Ethical Acceptability Issues}

All the approaches for elephants' welfare assessments described above have been developed for a target elephant subpopulation, mainly zoo animals, that differs from semi-captive elephants involved in interactive animal-visitor experiences in South Africa. Most of the approaches had undergone some form of reliability and validity testing, usually, intra or inter-rater concordance, as brilliantly reviewed by Williams et al. [14]. However, to our knowledge, the issue regarding whether the method developed could be suitable to be applied to other subpopulations of animals in a different management situation (i.e., external validity issue) was never investigated. An independent approach, taking into account the external validity issue, was initiated in 2013 by researchers of the University of Padua [54,55], as part of a running project including science, ethics, and education (of staff and tourists) and focusing on welfare, conservation, and their connections. The project included the proposal for two protocols, one for evaluating the welfare effects of the elephants' general housing and management (i.e., housing and management protocol, HMP) and one for issues specifically related to the acceptability of interactions with visitors (i.e., animal-visitor interactions protocol, AVIP). Both protocols merge a scientific approach 
with ethical analysis (see Appendix A, Table A1 for details) in order to evaluate the overall welfare of the elephants kept in semi-captive conditions and involved in interactions with visitors in South Africa.

The proposed AVIP was adapted from a general animal-visitor interactions ethical evaluation protocol that was described elsewhere [21,56]. The HMP consisted of two procedures, one derived from the results obtained from animals in a different context ("external procedure") and one based almost exclusively on results of preliminary ad hoc studies targeting the semi-captive, visitor interacting elephants under study (i.e., "internal procedure"), using different methods and paradigms [40,50,52, 57-64] and then comparing their results (Appendix A, Table A1).

As can be seen from the very short description of the project in Appendix A, Table A1, a protocol for welfare assessment which explicitly addresses the issue of external validity and includes a procedure that is based uniquely on data collected on the target population can be very complex and demanding in terms of time and resources. Other ways to address the external validity issue when designing a project are possible. However, the need to generate data and validate the parameters within the target subpopulation, is likely to result in a demanding project in any case.

An alternative is to directly apply a protocol designed for zoo elephants to semi-captive interacting elephants and then try to assess its reliability and validity. However, the absence of a "golden standard" known external criterion $[61,65]$ makes assessing welfare without conducting experiments to validate the imported parameters in the target population itself more likely to incur validity problems, which could be very difficult to be detected a posteriori. Therefore, caution should be used when exporting welfare assessing methods to other subpopulations than the one they have been designed for. More scientific research is needed to address the external validity issue in welfare assessment.

The idea that there could be specific welfare problems in different subpopulations of animals, and that preliminary data on which to develop a welfare assessment protocol should be collected on the target populations itself is suggested by Pritchard et al. [66] for working equines. However, to our knowledge, the issue of the external validity of protocols and indicators used to assess welfare in animals has not yet been explicitly addressed in the scientific literature. In July 2019, a search on Web of Science [67] using "external validity" and "welfare assessment" as keywords resulted in zero entries. However, recently some authors have begun expressing concerns on the possible limitations of applying a known validated welfare assessment protocol to farming systems differing from those for which it had been created $[68,69]$. Scott et al. [70] in their detailed review on quality of life assessment for humans and other animals does not discuss external validity among the important facets of validity to be addressed. This is surprising, because external validity is recognized to be an important facet of validity in other contexts (e.g., for canine temperament studies [71,72]). In biomedical research, the low external validity of the findings is acknowledged as a problem and there is scientific research on how to improve it (e.g., [73] on whether standardization of the living conditions increases or decreases external validity). The concern about the external validity of the findings extends to human welfare research (e.g., [74] on sampling methods to increase it).

\section{Hints to the Existence of Relevant Differences in Welfare Evaluation between Zoo and Semi-Captive Elephants}

The project initiated by Padua University was ambitious, and until now, alongside a range of educational activities, it was possible to complete the designing of the protocol AVIP and its application to the zoo context [21] and some preliminary studies [55]. The issues of external validity and ethical acceptability were explored in a questionnaire-based survey that involved experts $[55,75]$.

\subsection{Results for the External Validity Issue}

Regarding the external validity issue, the questionnaire asked experts the following:

1. Which were the five most important topics for captive elephants (and the most relevant parameters to be used to evaluate them, as in Whay [60]? 
2. Did the five most important elephant welfare topics identified have equal relevance for semi-captive compared to zoo-bound individuals?

Further sections asked experts to identify behavioral correlates of positive and negative emotions in elephants, questions on stockmanship, on health protocols to apply, and opinions on ethically relevant topics concerning captivity and involvement in activities with tourists. The questionnaire used for the study [55] is included in Appendix A as Table A2. Seventy-nine experts (defined as keepers, researchers, facilities managers, vets with at least five years of experience with African elephants, and government legislative authorities and animal rights activists dealing with African elephants) were contacted. Forty experts answered and twelve completed the survey on time, whose details are given in Appendix A, as Table A3. The results of the survey are detailed in Tables 1 and 2.

Half of the experts stated that at least some of the issues they ranked as the five most important to captive elephants' management had a different level of relevance for semi-captive individuals. Of the 55 answers given regarding equal relevance, 13 (23.6\%) were negative answers. When the issues were grouped into 12 categories (i.e., social life, psychological alterations, foot pathologies, exhibit design, diet, musculoskeletal problems (including arthritis), environmental and behavioral enrichment (including occupational options), weight imbalances, training, use of chains, stability of the group, and reproductive management), eight categories (66.7\%) were deemed to differ in relevance between zoo and semi-captive elephants by at least one expert. It is noteworthy that all the issues deemed of different relevance at least by some experts (e.g., musculoskeletal and foot health, diet and weight, and interaction with the environment) corresponded to parameters included as important in some of the previous literature about welfare assessments of zoo elephants $[41,45,46,49,52,53]$. The main differences stated by experts regarding the welfare topics are summarized in Table 2.

Although the abovementioned findings result from a pilot with relatively low sample size, they show that scientists deem the condition of semi-captive elephants different from that of zoos' ones from a welfare assessment point of view. The results of this study, hence, suggest the existence of a possible external validity issue when using the same parameters and evaluation protocols in the two situations. 
Table 1. Results of the survey regarding issues affecting the welfare of elephants in captivity and possible differences in relation to semi-captive individuals. E stands for whether the issue had equal relevance for semi-captive individuals compared to zoo ones; $\mathrm{Y}$ means that the experts answered it had equal relevance; and $\mathrm{N}$ means it had different relevance.

\begin{tabular}{|c|c|c|c|c|c|c|c|c|c|c|}
\hline Expert & 1st Issue & $\mathrm{E}$ & 2nd Issue & $\mathrm{E}$ & 3rd Issue & $\mathrm{E}$ & 4th Issue & $\mathrm{E}$ & 5th Issue & E \\
\hline 1 & $\begin{array}{c}\text { Social- } \\
\text { environment }\end{array}$ & $\mathrm{Y}$ & Free of chain & $\mathrm{N}$ & $\begin{array}{c}\text { Environmental } \\
\text { Enrichment/Behavioral } \\
\text { Enrichment }\end{array}$ & $\mathrm{N}$ & $\begin{array}{c}\text { Food (and water) ad } \\
\text { libitum }\end{array}$ & $\mathrm{N}$ & $\begin{array}{l}\text { Breeding situation } \\
\text { and Family } \\
\text { management }\end{array}$ & $\mathrm{Y}$ \\
\hline 2 & $\begin{array}{c}\text { Social- } \\
\text { environment }\end{array}$ & $\mathrm{Y}$ & $\begin{array}{l}\text { Free of chains or } \\
\text { other restricting } \\
\text { measures }\end{array}$ & $\mathrm{N}$ & $\begin{array}{c}\text { Environmental } \\
\text { Enrichment/Behavioral } \\
\text { Enrichment }\end{array}$ & $\mathrm{N}$ & $\begin{array}{l}\text { Free choice of food } \\
\text { given throughout } \\
\text { the day }\end{array}$ & $\mathrm{N}$ & $\begin{array}{l}\text { Proving a breeding } \\
\text { possibilities and } \\
\text { family life }\end{array}$ & $\mathrm{Y}$ \\
\hline 3 & Foot disease & $\mathrm{N}$ & Arthritis & $\mathrm{N}$ & $\begin{array}{l}\text { Psychological } \\
\text { distress }\end{array}$ & $\mathrm{N}$ & Social- Environment & $\mathrm{N}$ & $\begin{array}{l}\text { Weight imbalance: } \\
\text { overweight or } \\
\text { underweight }\end{array}$ & $\mathrm{N}$ \\
\hline 4 & Health & $\mathrm{Y}$ & Behavior & $\mathrm{Y}$ & Social structure & $\mathrm{Y}$ & Facilities & $\mathrm{Y}$ & Management & $Y$ \\
\hline 5 & $\begin{array}{c}\text { Social- } \\
\text { environment }\end{array}$ & Y & Environment & $\mathrm{Y}$ & $\begin{array}{l}\text { Training } \\
\text { relationship }\end{array}$ & $\mathrm{Y}$ & Enrichment & $\mathrm{Y}$ & $\begin{array}{l}\text { Occupational } \\
\text { options }\end{array}$ & Y \\
\hline 6 & $\begin{array}{c}\text { Negative } \\
\text { Affective States }\end{array}$ & $\mathrm{Y}$ & $\begin{array}{l}\text { High stereotypic } \\
\text { behavior rates }\end{array}$ & $\mathrm{Y}$ & Social- environment & $\mathrm{Y}$ & $\begin{array}{l}\text { Hormone } \\
\text { Imbalance }\end{array}$ & $\mathrm{Y}$ & $\begin{array}{l}\text { Foot and Joint } \\
\text { Health }\end{array}$ & Y \\
\hline 7 & Foot health & $\mathrm{Y}$ & $\begin{array}{l}\text { Musculo-skeletal } \\
\text { health }\end{array}$ & $\mathrm{Y}$ & Nutrition & $\mathrm{Y}$ & $\begin{array}{l}\text { Behavioral/ } \\
\text { Enrichment }\end{array}$ & $\mathrm{N}$ & Husbandry training & Y \\
\hline 8 & $\begin{array}{l}\text { Access to water } \\
\text { and food }\end{array}$ & Y & $\begin{array}{l}\text { Adequate space } \\
\text { and safe housing }\end{array}$ & $\mathrm{Y}$ & $\begin{array}{l}\text { Training, positive } \\
\text { and negative } \\
\text { reinforcement }\end{array}$ & $\mathrm{Y}$ & Health & $\mathrm{Y}$ & Social-environment & $\mathrm{Na}$ \\
\hline 9 & $\begin{array}{l}\text { Psychological } \\
\text { alterations }\end{array}$ & $\mathrm{Y}$ & $\mathrm{Na}$ & & $\mathrm{Na}$ & & $\mathrm{Na}$ & & $\mathrm{Na}$ & \\
\hline 10 & $\begin{array}{c}\text { Mental behavioral } \\
\text { health }\end{array}$ & $\mathrm{Y}$ & Social-environment & $\mathrm{Y}$ & $\begin{array}{l}\text { Physical } \\
\text { Health/physical } \\
\text { well being }\end{array}$ & $\mathrm{Y}$ & Foot condition & $\mathrm{Y}$ & $\begin{array}{l}\text { Space and exhibit } \\
\text { design }\end{array}$ & Y \\
\hline 11 & $\begin{array}{l}\text { Freedom from } \\
\text { thirst and hunger }\end{array}$ & Y & Freedom of shelter & $\mathrm{Y}$ & $\begin{array}{l}\text { Freedom from pain, } \\
\text { injury, and disease }\end{array}$ & $\mathrm{Y}$ & $\begin{array}{l}\text { Freedom to express } \\
\text { species-specific } \\
\text { behavior }\end{array}$ & $\mathrm{Y}$ & $\begin{array}{l}\text { Freedom from fear } \\
\text { and distress }\end{array}$ & Y \\
\hline 12 & $\begin{array}{l}\text { Musculo-skeletal } \\
\text { disorders }\end{array}$ & $\mathrm{Y}$ & Foot disease & $\mathrm{Y}$ & Obesity & $\mathrm{N}$ & $\begin{array}{l}\text { Injuries/stress due } \\
\text { to the inadequate } \\
\text { social environment }\end{array}$ & $\mathrm{Y}$ & $\begin{array}{l}\text { Stereotypic } \\
\text { behavior }\end{array}$ & Y \\
\hline
\end{tabular}


Table 2. Differences stated by experts between zoo elephants and semi-captive ones regarding main welfare relevant topics.

\begin{tabular}{|c|c|}
\hline Expert & $\begin{array}{l}\text { Stated Differences Regarding Welfare Indicators in Semi-Captive Elephants as Compared } \\
\text { to Zoo Ones }\end{array}$ \\
\hline 1 & $\begin{array}{l}\text { Issue } n^{\circ} 2 \text { (free of chains) and } n^{\circ} 3 \text { (enrichment) are less important for semi-captive elephants, } \\
\text { whereas issue } n^{\circ} 5 \text { (breeding/Family management) is more relevant than for zoo elephants. } \\
\text { Issue } n^{\circ} 4 \text { (food (and water) ad libitum) less relevant for semi-captive elephants because they } \\
\text { can search for them when free to roam. }\end{array}$ \\
\hline 2 & $\begin{array}{l}\text { Issue } n^{\circ} 2 \text { (free of chains) is less of a problem for semi-captive elephants because if they are } \\
\text { chained, they are usually chained for shorter periods, usually at night. Issue } n^{\circ} 3 \text { (enrichment) } \\
\text { and issue } n^{\circ} 4 \text { (free choice of food) are less important for semi-captive elephants because, for a } \\
\text { part of the day they are free to roam and forage in a larger environment where they can } \\
\text { express their natural behavior. }\end{array}$ \\
\hline 3 & $\begin{array}{l}\text { Issue } n^{\circ} 1 \text { (foot disease) and issue } n^{\circ} 2 \text { (arthritis) are less relevant for semi-captive animals } \\
\text { because their movement is less restricted. Issue } n^{\circ} 3 \text { (psychological distress) is less relevant for } \\
\text { semi-captive elephants because they are less deprived than zoo ones. Issue } n^{\circ} 4 \text { (social } \\
\text { alienation or isolation) and issue } n^{\circ} 5 \text { (weight imbalance) are more common in a strictly captive } \\
\text { setting, although their relevance for the affected animal is the same in both contexts. }\end{array}$ \\
\hline 7 & Issue $n^{\circ} 4$ (behavioural/enrichment) is stated to differ, but no further explanation is given. \\
\hline 12 & $\begin{array}{l}\text { Issue } n^{\circ} 3 \text { (obesity) is less common in a semi-captive setting, although its relevance for the } \\
\text { affected animal is the same in both contexts. }\end{array}$ \\
\hline
\end{tabular}

\subsection{Results about the Ethical Acceptability of Procedures}

When discussing the welfare conditions of semi-captive elephants in South Africa as being different from that of zoos' ones, it is important to discuss also, the ethical acceptability of procedures that are typical of semi-captive animal-visitor interactions. As stated in $[15,16]$, ethics play a role not only in deciding what level of welfare to assure to animals, but also in the decisions about which practices to accept or to avoid in managing each specific animal population. Welfare experts assessing the acceptability of practices are likely to be influenced by the context and culture they are part of, making their evaluation (of the practice) different for different subpopulations of animals. If this is the case, an experts' evaluation of the acceptability of a practice can lead to that practice being either included or excluded from a management system. Because these different practices can influence welfare, their inclusion or exclusion is highly likely to influence the quality of life of the animals belonging to that subpopulation. Therefore, ethics is crucial to assess specific, controversial, welfare-relevant issues by focusing on their acceptability, which can vary depending on the animal population studied. Moreover, when assessing welfare, the level of welfare found in one specific situation must be compared to a standard threshold to determine whether acceptable or not. This level of acceptability, or the benchmark, will be determined by the findings of the evaluation procedure of experts and what they perceive as acceptable, thus highlighting the importance of the acceptability issue where welfare is concerned.

The survey in Appendix A, Table A2 included a section specifically investigating the ethical acceptability of procedures that are commonly applied with the semi-captive elephant subpopulation. The experts were asked to choose among three options: totally acceptable, partially acceptable, and totally unacceptable. In case experts chose the option "partially acceptable," they were asked to specify under which conditions the procedure was acceptable. The list of procedures and results of the survey are detailed in Table 3. 
Table 3. Results of the acceptability survey.

\begin{tabular}{|c|c|c|c|c|}
\hline $\begin{array}{l}\text { Management } \\
\text { Practice }\end{array}$ & $\begin{array}{c}\text { Totally } \\
\text { Acceptable }\end{array}$ & $\begin{array}{c}\text { Partially } \\
\text { Acceptable }\end{array}$ & $\begin{array}{c}\text { Totally } \\
\text { Unacceptable }\end{array}$ & Notes and Main Specifications Given \\
\hline Free contact & 2 & 3 & 5 & $\begin{array}{l}2 \text { missing answers; if the animal needs medical } \\
\text { care/never for medical interventions/never for } \\
\text { aggressive, nervous elephants or elephants in } \\
\text { musth; it is difficult to eradicate, it is cultural }\end{array}$ \\
\hline $\begin{array}{l}\text { Interaction with } \\
\text { tourists }\end{array}$ & 1 & 4 & 4 & $\begin{array}{l}3 \text { missing answers; only if there is a barrier and } \\
\text { tourists receive an education. Only elephants with } \\
\text { the right disposition, with some training. Trained } \\
\text { with positive reinforcement methods }\end{array}$ \\
\hline $\begin{array}{l}\text { Chaining during } \\
\text { riding }\end{array}$ & 0 & 2 & 7 & $\begin{array}{l}3 \text { missing answers; when elephants are free to } \\
\text { roam it is acceptable when tourists get on and off }\end{array}$ \\
\hline $\begin{array}{l}\text { Walking with } \\
\text { tourists }\end{array}$ & 1 & 4 & 4 & $\begin{array}{l}3 \text { missing answers; only if there is a barrier, only if } \\
\text { there is a trainer, only if they only walk side by } \\
\text { side, only if elephants can walk off when the walk } \\
\text { is finished }\end{array}$ \\
\hline Enrichment & 8 & 1 & 0 & $\begin{array}{l}3 \text { missing answers; acceptable only if not used in } \\
\text { place of granting the elephants the necessary } \\
\text { freedoms }\end{array}$ \\
\hline $\begin{array}{l}\text { Training for } \\
\text { medical procedures }\end{array}$ & 8 & 2 & 0 & $\begin{array}{l}2 \text { missing answers; positive reinforcement methods } \\
\text { only, protected contact }\end{array}$ \\
\hline Training for shows & 1 & 4 & 4 & $\begin{array}{l}2 \text { missing answers; only if the behaviors trained are } \\
\text { natural behaviors, only if there is an educational } \\
\text { goal, elephants must be monitored }\end{array}$ \\
\hline $\begin{array}{l}\text { Training as } \\
\text { enrichment }\end{array}$ & 4 & 5 & 0 & $\begin{array}{l}2 \text { missing answers; only if it is not the only form of } \\
\text { enrichment, only positive reinforcement methods, } \\
\text { repetition of already learned behaviors is not } \\
\text { enriching, acquiring new ones is likely to be }\end{array}$ \\
\hline $\begin{array}{l}\text { Training with } \\
\text { negative } \\
\text { reinforcement }\end{array}$ & 1 & 3 & 5 & $\begin{array}{l}3 \text { missing answers; only to stop dangerous } \\
\text { behavior, limited holds are ok, should be } \\
\text { monitored }\end{array}$ \\
\hline $\begin{array}{l}\text { "Breaking in" } \\
\text { methods }\end{array}$ & 1 & 0 & 7 & 3 missing answers; 1 no opinion \\
\hline
\end{tabular}

It is noteworthy that there was no agreement among the experts on the acceptability of any of the procedures. This notwithstanding, there was more agreement in favor of the acceptability of some procedures, such as enrichment and training for medical practices. On the contrary, procedures such as chaining and "breaking in" were mostly seen as unacceptable. Among the more controversial procedures were those referring to interactions with tourists, including walking with tourists and training for shows: one expert deemed them totally acceptable, while others were equally divided between finding them partially acceptable and totally unacceptable. Additionally, free contact between elephants and people divided experts, the majority of them finding the procedure unacceptable.

It is interesting to note that one expert cited as a reason for the acceptability of free contact between elephants and people, it being part of the culture of the people involved. Free (i.e., unprotected) contact is a dangerous practice, which can often be seen in facilities offering "elephant experiences" to tourists in Southern Africa. Accidents happen, resulting in fatalities among the handlers (e.g., [76]). On the contrary, free contact with elephants is discouraged by zoo associations in western zoos, where protected contact is recommended $[26,77,78]$. In a sense, chaining, the use of punishment and/or of negative reinforcement, and the "breaking-in" procedure $[29,76]$ to get young elephants used to being tame around people can be seen as a way to attempt decreasing the risks linked to unprotected contact [79]. The coercive form of breaking in is awfully cruel and does not deserve any discussion here [80]. Even the other procedures can be at high risk of being detrimental for the welfare of the animals involved; and they increase stress and frustration, thus increase the risks they are supposed to mitigate. 
In the case of chaining, however, the way elephants are accustomed to wearing the chains, as well as the situation and the length of time they have to wear them and other variables, can influence the likelihood that the procedure has a welfare relevant effect on the animals. Whether you train an elephant to accept a chain or tether, or you use a chain or tether to train an elephant makes a huge difference in this discussion. Some people feel strongly that an elephant trained to take a chain is less stressed when the tether or chain is used during the application of medical procedures, thus creating safe options for veterinarians and the elephant. This brings to the fore the ethical consideration of whether welfare is compromised if an elephant is not desensitized/positively conditioned to any restraining device, whether a tether or chain or mechanical restraining device. For some people, tethering an elephant is acceptable also in other situations than medical procedures, provided that, due to appropriate training, the elephants have not developed a negative perception of the chain or tether. Of course, it is also important that the animals have a non-negative perception of the whole situation in which they are tethered, not only of being tethered per se. However, to what extent training a wild animal to be restrained is equally as acceptable as training a domestic one is open to debate. Moreover, the general aim for which animals are restrained or subjected to other management procedures is likely to be relevant when deciding on acceptability. On the other hand, there are people who are concerned by any form of restraint applied to a wild animal, independently from the method used to accustom the animal to it, from the aim of the restraint or even from the perception that the animal has of the situation.

For these reasons, the discussion of acceptability of procedures should be conducted on the level of each subpopulation of wild animals under investigation, and ethical arguments should not be easily exported from other contexts.

\section{Conclusions}

As wild animals could be subjected to a range of different management situations on the wild-captive continuum, ethical issues, scientific protocols, and indicators derived from studies conducted on animals on one position of the range (e.g., zoo animals) and found to be suitable for that subpopulation may not be suitable for other populations of animals of the same species. Given the lack of an external golden standard in welfare science, against which to verify whether the welfare assessment method used is indeed assessing the relevant aspects of welfare for those specific animals and all of them, the risk of not detecting a lack of suitability is high. If the method used to assess welfare is not valid, then the risk of not ensuring ethically acceptable levels of care and welfare for those animals is likely to be high. Experts appear to be aware that welfare issues that can be important for one subpopulation of animals may fail to be of equal importance for other subpopulations. For example, when asked about possible differences between zoo and semi-captive elephants, experts stated that semi-captive elephants were less likely to be affected by physical problems due to lack of exercise and restraint. They were also less likely to be affected by psychological ones derived from not being able to have access to an environment in which they could express their natural behavior and find suitable resources, at least for part of their time. However, differences between different subpopulations may not be confined only to likelihood of occurrences. For example, obese or lame elephants are likely to be rarer in semi-captive situations. However, if a semi-captive elephant is obese or lame, could he/she be more affected by his/her condition than a zoo one? Could he/she be more frustrated as she cannot take full advantage of the opportunity to roam free over a larger environment with the group he/she belongs to? Studies explicitly evaluating the differences, both in terms of likelihood of occurrence/prevalence (at the population level) and in terms of severity of effects at the individual level are needed. As Turner highlighted for extensive farm-animal breeding [81], focus should be directed also on assessing the availability, use, and success of contingencies preventing suffering and on stockmanship. It is evident that stockmanship becomes even more important in elephants involved in animal-visitor interactions (AVIs), and therefore, it should be investigated in more depth in this sub-population. 
Moreover, the involvement of different animal subpopulations in management procedures whose ethical acceptability is controversial can vary both qualitatively and quantitatively. It is, therefore important for the scientific community to be aware and to discuss the issue of exporting findings and protocols developed in zoo animals to other populations that are managed differently. The approach suggested by this study can help to foster the role of experts in assessing the external validity and acceptability of procedures when exporting findings. In general, further interdisciplinary studies, like the one proposed by the AVIP protocol [21], are needed to investigate the complex issue of tourist interactions with animals in their differences along the "wild-captive continuum." Further studies are needed as well to involve not only experts, but also the other stakeholders in the discussion about the issue of exporting findings along this continuum.

\section{Patents}

Independently from their points of view on the different situations in which animals can be found in the "wild-captive continuum," and from the different regulations of practices involving wild animals in different countries, the authors of the present paper recognize the overriding importance of working together with all stakeholders and role-players to ensure that every effort is made to grant these wild animals the highest possible welfare standards.

Author Contributions: Conceptualization, S.N.; methodology, S.N. and B.d.M.; data curation and analysis, S.N.; resources, G.V. and K.A.R.; writing-original draft preparation, S.N., E.S., and L.F.; writing-review and editing, B.d.M., S.N., E.S., L.F., G.V., and K.R.; supervision, B.d.M.; project administration, B.d.M.; funding acquisition, B.d.M.

Funding: This project was supported by public/national (MIUR) and private (Parco Natura Viva and Safari Ravenna) funds (DOR1774919).

Acknowledgments: Thanks to Elisa Bettin for help with gathering the expert survey data, the experts who answered, and to Bernard Rollin and Paola Valsecchi for critical reading of the manuscript.

Conflicts of Interest: The authors declare no conflict of interest. The funders had no role in the design of the study; in the collection, analyses, or interpretation of data; in the writing of the manuscript, or in the decision to publish the results. 


\section{Appendix A}

Table A1. Summary of the main methods and steps included in the project for the housing and management protocol (HMP).

\begin{tabular}{|c|c|c|c|c|}
\hline Step & $\begin{array}{l}\text { Methodological } \\
\text { Approaches }\end{array}$ & Specific Studies (If $>1$ ) & Brief Description and Relevant References & Reliability/Validity Checking \\
\hline \multirow{4}{*}{$\begin{array}{l}\text { Identifying parameters } \\
\text { to be included in the tool } \\
\text { using an internal } \\
\text { procedure (IP) }\end{array}$} & \multirow{2}{*}{$\begin{array}{l}\text { Consensus } \\
\text { procedures-Delphi and } \\
\text { Ethical Delphi (CP) }\end{array}$} & $\begin{array}{l}\text { Stakeholders Consensus } \\
\text { (SC) }\end{array}$ & $\begin{array}{l}\text { Analogously to what has been done by Gurusamy } \\
\text { et al. [58] and by Chadwick et al. [59], the point of } \\
\text { view of stakeholders will be collected. } \\
\text { Stakeholders will be asked to rate the effect of } \\
\text { possible welfare issues, identified during a pilot } \\
\text { study, on both single elephants and the population, } \\
\text { and a Delphi procedure will be used to approach } \\
\text { consensus. }\end{array}$ & Consensus among participants. \\
\hline & & Expert Consensus (EC) & $\begin{array}{l}\text { Following the classical Delphi and the Ethical } \\
\text { Delphi methods (e.g., [60-62]), each expert in the } \\
\text { panel is asked to: (a) rate risk factors and issues, } \\
\text { which could affect the welfare state of captive } \\
\text { elephants; (b) identify relevant measures, } \\
\text { including both bad and good welfare criteria, and } \\
\text { possible relevant differences for "semi-captive" } \\
\text { individuals. }\end{array}$ & Consensus among participants. \\
\hline & \multirow[t]{2}{*}{$\begin{array}{l}\text { Experimental approach } \\
\text { validating behavioral } \\
\text { correlates of positive and } \\
\text { negative mental states in } \\
\text { elephants (EA) }\end{array}$} & Emotional valence study & $\begin{array}{l}\text { Detailed analysis of the behavior (as in Young et al. } \\
\text { [63]), expressed by elephants during specific } \\
\text { situations, whose emotional value has already } \\
\text { been experimentally established (using avoidance } \\
\text { or motivation paradigms), is used to identify } \\
\text { behavioral correlates of positive and negative } \\
\text { mental states). Physiological parameters (such as } \\
\text { salivary cortisol) are also evaluated. }\end{array}$ & $\begin{array}{l}\text { Intra and inter-observer } \\
\text { reliabilities checked for the } \\
\text { behavioral observations. } 30 \% \text { of } \\
\text { the videos also analyzed by a } \\
\text { blind observer, and qualitatively } \\
\text { assessed by experts. }\end{array}$ \\
\hline & & $\begin{array}{c}\text { Study on anticipatory } \\
\text { behaviour }\end{array}$ & As in Clegg et al. [64]. & $\begin{array}{l}\text { Intra and inter-observer } \\
\text { reliability checked for the } \\
\text { behavioral observations. }\end{array}$ \\
\hline
\end{tabular}


Table A1. Cont.

\begin{tabular}{|c|c|c|c|c|}
\hline Step & $\begin{array}{l}\text { Methodological } \\
\text { Approaches }\end{array}$ & Specific Studies (If $>\mathbf{1}$ ) & Brief Description and Relevant References & Reliability/Validity Checking \\
\hline & Correlational Study (CS) & & $\begin{array}{l}\text { Data on feeding, freedom of movement, physical } \\
\text { comfort, health status, appropriate } \\
\text { social/non-social behavior, human-elephant } \\
\text { interactions and stockmanship, avoidance of } \\
\text { negative and presence of positive emotions, control } \\
\text { over the environment gathered using structured } \\
\text { interviews, ad hoc developed questionnaires, } \\
\text { direct observation, quantitative and qualitative } \\
\text { videotaped behavioral observation, analysis of } \\
\text { cortisol concentrations in suitable matrices, and } \\
\text { health evaluation (clinical visit and medical and } \\
\text { reproductive entries) for all South African } \\
\text { semi-captive elephants. Correlations between } \\
\text { income measures (e.g., characteristics of the } \\
\text { facilities) and outcome measures (e.g., behavioral } \\
\text { signs of negative or positive psycho-physical } \\
\text { states), are statistically investigated as in Carlstead } \\
\text { et al. [40]. A genetic study of the captive elephant } \\
\text { population also planned. }\end{array}$ & $\begin{array}{l}\text { Inter-observer and test-retest } \\
\text { reliabilities checked. Videos } \\
\text { analyzed (qualitatively and } \\
\text { quantitatively) also by blind } \\
\text { observers and qualitatively by } \\
\text { experts. }\end{array}$ \\
\hline Unifying IP parameters & & & $\begin{array}{l}\text { EC + EA results are compared and used to } \\
\text { interpret CS results. The valence to be attributed to } \\
\text { behavioral outputs recorded in CS is identified } \\
\text { using EC + EA results. }\end{array}$ & \\
\hline $\begin{array}{l}\text { Identifying parameters } \\
\text { to be included in the tool } \\
\text { using an external } \\
\text { procedure (EP) }\end{array}$ & $\begin{array}{l}\text { Welfare Quality-based } \\
\text { "Elewell" (EW) }\end{array}$ & & $\begin{array}{l}\text { After a detailed literature review (e.g., [50,52]) and } \\
\text { expert opinion seeking on the target species, an } \\
\text { approach similar to the European Welfare } \\
\text { Quality }{ }^{\circledR} \text { project for some domestic species was } \\
\text { developed. It has then been applied to } \\
\text { semi-captive elephants in a pilot study. }\end{array}$ & $\begin{array}{l}\text { Inter-observer intra-observer } \\
\text { (on videos) and test-retest } \\
\text { reliabilities checked. }\end{array}$ \\
\hline
\end{tabular}


Table A1. Cont.

\begin{tabular}{|c|c|c|c|c|}
\hline Step & $\begin{array}{l}\text { Methodological } \\
\text { Approaches }\end{array}$ & Specific Studies (If $>\mathbf{1}$ ) & Brief Description and Relevant References & Reliability/Validity Checking \\
\hline \multirow[t]{2}{*}{$\begin{array}{l}\text { Verifying the chosen } \\
\text { parameters }\end{array}$} & $\begin{array}{c}\text { Comparing IP and EP } \\
\text { results }\end{array}$ & & $\begin{array}{l}\text { IP and EP results in terms of welfare parameters } \\
\text { will be compared in order to investigate the } \\
\text { biological validity issue. }\end{array}$ & External validity issue tackled. \\
\hline & $\begin{array}{l}\text { Cognitive bias paradigm } \\
\text { (CB) }\end{array}$ & & $\begin{array}{l}\text { A cognitive bias paradigm [57] experiment } \\
\text { performed on two groups of elephants: eight } \\
\text { elephants resulted from IP + EP to have highest } \\
\text { welfare levels vs eight elephants (similar in } \\
\text { temperament, gender, age, history) found to have } \\
\text { the lowest. The expected result is to find a } \\
\text { pessimistic bias in the elephants found to have the } \\
\text { lowest levels. }\end{array}$ & \\
\hline Draft & & & $\begin{array}{l}\text { Protocol draft created using the parameters found } \\
\text { to be feasible, suitable, reliable and valid. }\end{array}$ & \\
\hline & $\begin{array}{c}\text { Stakeholders and } \\
\text { Role-players } \\
\text { Discussion(SRD)-Ethical } \\
\text { Matrix }\end{array}$ & & $\begin{array}{l}\text { Discussion among all stakeholders and } \\
\text { role-players in a workshop using the Ethical } \\
\text { Matrix tool, in order to reach consensus on } \\
\text { weighing the parameters and establishing a } \\
\text { minimum acceptability threshold (the results of the } \\
\text { protocol represent the stakeholder "elephants"). }\end{array}$ & \\
\hline Tool & & & On facility welfare assessment tool created. & \\
\hline
\end{tabular}


Table A2. Questionnaire. It was designed and used by the University of Padua team for the cited expert opinion survey [55,75].

1. Welfare issue ${ }^{\circ} 1$ to be assessed:

2. How important is welfare issue $\mathbf{n}^{\circ} \mathbf{1}$ to each individual animal in the context of your expertise? $(0=$ minimum; $5=$ maximum $)$

Score: $\quad \begin{array}{llllll}0 & 1 & 2 & 3 & 4 & 5\end{array}$

If you can, explain the reason of choosing this score:

3. How important is welfare issue $\mathbf{n}^{\circ} \mathbf{1}$ to the captive group of animal in your context? $(0=$ minimum; $5=$ maximum $)$

Score: $\quad \begin{array}{lllllll} & 0 & 1 & 2 & 3 & 4 & 5\end{array}$

If you can, explain the reason of choosing this score:

4. Is welfare issue $n^{\circ} 1$ equally relevant in semi-captive context?

$\square$ Yes, always $\quad$ No

If it doesn't, which is more important?

\begin{tabular}{|c|c|c|c|c|c|c|c|}
\hline \multirow{2}{*}{$\begin{array}{l}\text { 5. What measures do you think are useful indicators of this welfare issue? Please } \\
\text { give brief methodological details. } \\
\text { Measure } n^{\circ} 1 \text { : }\end{array}$} & \multicolumn{7}{|c|}{$\begin{array}{l}\text { 6. How is this measure important to indicate the issue? }(0=\text { minimum; } 5= \\
\text { maximum })\end{array}$} \\
\hline & Score: & 0 & 1 & 2 & 3 & 4 & 5 \\
\hline Brief details: & \multicolumn{7}{|c|}{ Comments: } \\
\hline \multicolumn{8}{|l|}{ Reference (if possible): } \\
\hline Measure $n^{\circ} 2:$ & Score: & 0 & 1 & 2 & 3 & 4 & 5 \\
\hline Brief details: & \multicolumn{7}{|c|}{ Comments: } \\
\hline \multicolumn{8}{|l|}{ Reference (if possible): } \\
\hline Measure $n^{\circ} 3:$ & Score: & 0 & 1 & 2 & 3 & 4 & 5 \\
\hline Brief details: & \multicolumn{7}{|c|}{ Comments: } \\
\hline
\end{tabular}

The above template was repeated other four times for other four welfare issues the expert could identify as the second to fifth most important.

31. In your opinion and within the context of your situation, how do African elephants express positive emotions? 
Table A2. Cont.

32. Among the ways elephants express positive emotions in context you described, which are the 3 most useful indicators to use in order to assess welfare in practice? Please describe only the situation of your context.

1. Elephant alone:

2. Elephant in herd:

3. Elephant in wild:

$\square$ I don't have this kind of experience

$\square$ I don't have this kind of experience

$\square$ I don't have this kind of experience

33. In your opinion and within the context of your situation, how do African elephants express negative emotions?

34. Among the ways elephants express negative emotions in context you described, which are the 3 most useful indicators to use in order to assess welfare in practice? Please describe only the situation of your context.

4. Elephant alone:

5. Elephant in herd:

6. Elephant in wild:

$\square$ I don't have this kind of experience

$\square$ I don't have this kind of experience

$\square$ I don't have this kind of experience

\section{On a scale from 1 to 100, how much does stockmanship affect the welfare of captive African elephants?}

- in trained animals:
Protected contact:
Free contact:
No contact:
Confined contact:

- in untrained animals: 


\section{Table A2. Cont.}

36. In your opinion, are there useful matters in order to evaluate welfare aspects specifically related to stockmanship in captive African Elephants?

Please list some related measures.

- in trained animals:

- Matter A1:

- Measure 1:

- Measure 2.

- Measure 3:

Matter B1:

- Measure 1:

- Measure 2:

- in not trained animats:

- Matter A2:

- Measure 1:

- Measure 2:

37. In your opinion, list the 3 most important factors that affect the way stockman treats animals.

1)

2)

38. List the 3 most important aspects for good captive African elephants stockmanship?

Aspect $n^{\circ} 1$ :

Aspect $n^{\circ}$ :

Aspect $n^{\circ} 3$ :
39. How much would this aspect improve the welfare of the African elephants? $(0=$ minimum $; 5=$ maximum $)$

\begin{tabular}{lllllll} 
Score: $\quad 0$ & 1 & 2 & 3 & 4 & 5 \\
\hline Comments: & & & & & \\
Score: $\quad 0$ & 1 & 2 & 3 & 4 & 5 \\
Comments: & & & & & \\
Score: $\quad 0$ & 1 & 2 & 3 & 4 & 5 \\
Comments: & & & & &
\end{tabular}


Table A2. Cont.

39. How do you consider the following situations about elephants in semi-captive condition?

- Free contact with handler

Totally acceptable

○ Partially acceptable

(please write conditions

Unacceptable

I have no opinion

- $\quad$ Training for medical procedures

Totally acceptable

- Partially acceptable

(please write conditions

Unacceptable

I have no opinion

- Training for show

- Totally acceptable

○ Partially acceptable

(please write conditions

Unacceptable

I have no opinion

- Training as enrichment

- Totally acceptable

- Partially acceptable

(please write conditions

Unacceptable

I have no opinion

- Training with negative reinforcement

Totally acceptable

- Partially acceptable

(please write conditions

Unacceptable

I have no opinion

- Breaking method to train the elephant

- Totally acceptable

Partially acceptable

Unacceptable

I have no opinion 
Table A2. Cont.

40. Please, feel free to give us some further comments or advices on assessing welfare in African elephants in captivity:

\section{HEALTH PROTOCOL.}

41. In your opinion, how important is regular health checks protocol for the welfare of captive African elephants? $(0=$ no importance; $10=$ fundamental $)$

Score: $\begin{array}{lllllllllll}0 & 1 & 2 & 3 & 4 & 5 & 6 & 7 & 8 & 9 & 10\end{array}$

42. Which are the six most important clinic/diagnostic procedures that should be adopted in order to assess the health status of African elephants in captivity?

\section{Measure $n^{\circ} 1$ : \\ Brief detail: \\ Is it possible to perform the procedure on: \\ - trained animals?:

$$
\begin{aligned}
& \bigcirc \quad \text { Yes, only during sedation } \\
& \bigcirc \quad \text { Yes, without sedation }
\end{aligned}
$$$$
0 \quad \text { No }
$$

- $\quad$ untrained animals?

$$
\begin{array}{ll}
\bigcirc & \text { Yes, only during sedation } \\
\bigcirc & \text { Yes, without sedation } \\
\bigcirc & \text { No }
\end{array}
$$

How often should it be repeated?

\begin{tabular}{l|}
\hline Measure $n^{\circ} 2:$ \\
\hline Brief detail:
\end{tabular}

Is it possible to perform the procedure on:

- $\quad$ trained animals?:

$$
\begin{array}{ll}
\bigcirc & \text { Yes, only during sedation } \\
\bigcirc & \text { Yes, without sedation } \\
& \text { No }
\end{array}
$$

- $\quad$ not trained animals?:

$$
\begin{array}{ll}
\bigcirc & \text { Yes, only during sedation } \\
\bigcirc & \text { Yes, without sedation } \\
& \text { No }
\end{array}
$$

Measure $n^{\circ} 4$ Brief detail:

Is it possible to perform the procedure on:

- $\quad$ trained animals?:

$$
\begin{array}{ll}
\bigcirc & \text { Yes, only during sedation } \\
\bigcirc & \text { Yes, without sedation } \\
& \text { No }
\end{array}
$$

- $\quad$ untrained animals?:

O Yes, only during sedation

Yes, without sedation

$\bigcirc \quad$ No

How often should it be repeated?

\section{Measure $n^{\circ} 5$}

Brief detail:

Is it possible to perform the procedure on:

- trained animals?:
$\bigcirc \quad$ Yes, only during sedation
Yes, without sedation
No

- $\quad$ not trained animals?:

$\begin{array}{ll}\bigcirc & \text { Yes, only during sedation } \\ \bigcirc & \text { Yes, without sedation } \\ & \text { No }\end{array}$


Table A2. Cont.

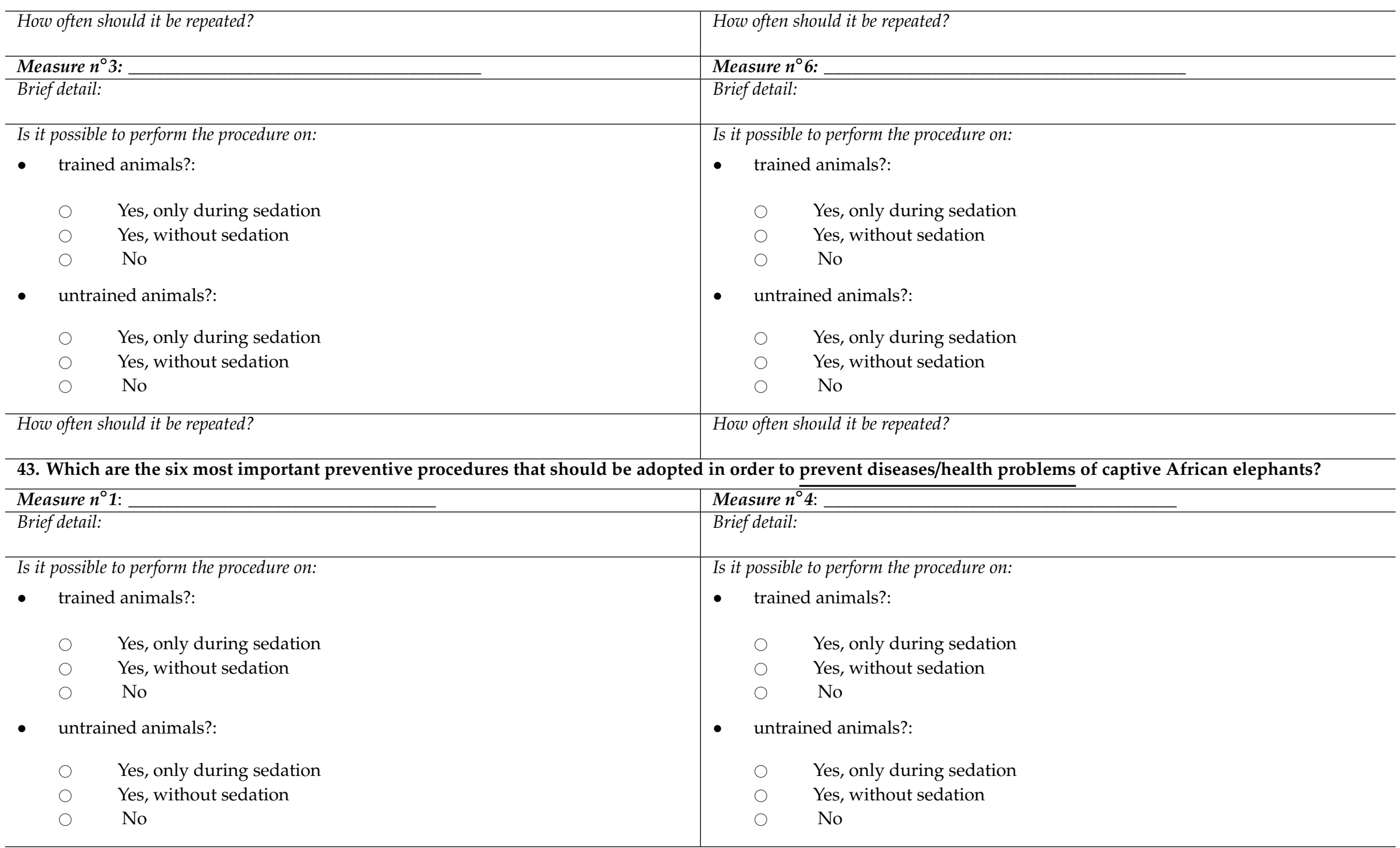


Table A2. Cont.

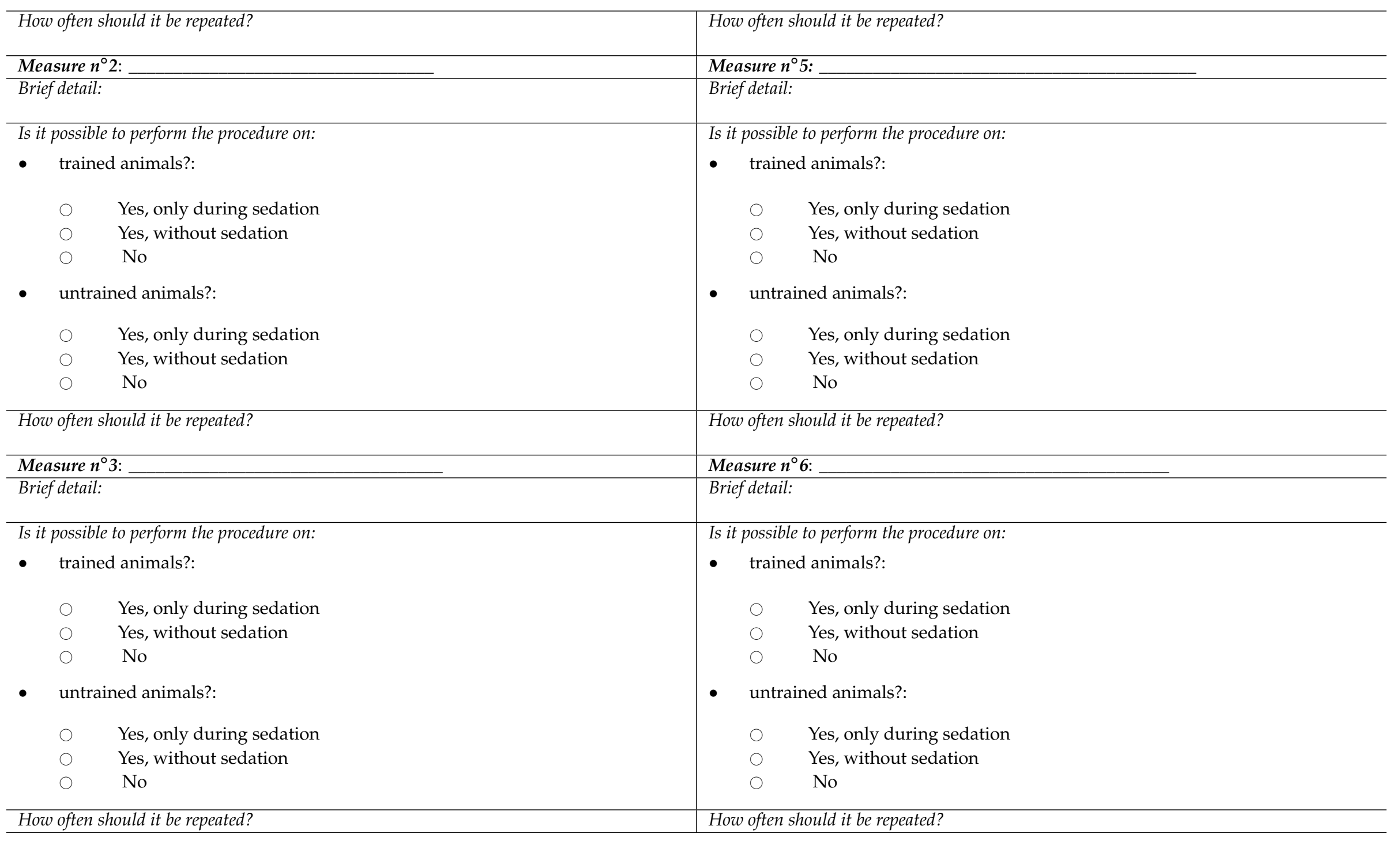


Table A3. Experts' demographic characteristics.

\begin{tabular}{|c|c|c|c|c|c|c|c|c|}
\hline \multirow{2}{*}{ Expert } & \multirow{2}{*}{ Sex } & \multirow{2}{*}{$\begin{array}{l}\text { Age Category } \\
\text { (Years) }\end{array}$} & \multirow{2}{*}{ Professional Involvement } & \multirow{2}{*}{ Education } & \multirow{2}{*}{ Continent } & \multicolumn{3}{|c|}{ Area of Expertise on Elephants } \\
\hline & & & & & & Species & Situation & Training Status \\
\hline 1 & M & $30-40$ & $\begin{array}{l}\text { Elephant trainer, keeper and } \\
\text { scientific consultant }\end{array}$ & MSc Biology & Europe & $\begin{array}{l}\text { Asian and } \\
\text { African }\end{array}$ & $\begin{array}{l}\text { Captive (zoo, } \\
\text { encampment) }\end{array}$ & $\begin{array}{l}\text { Both trained } \\
\text { and untrained }\end{array}$ \\
\hline 2 & $\mathrm{~F}$ & Over 50 & Scientist, scientific advisor & $\mathrm{MSc}, \mathrm{PhD}$ & Europe & $\begin{array}{l}\text { Asian and } \\
\text { African }\end{array}$ & $\begin{array}{l}\text { Wild, } \\
\text { Semi-captive, } \\
\text { Captive }\end{array}$ & $\begin{array}{l}\text { Both trained } \\
\text { and untrained }\end{array}$ \\
\hline 3 & $\mathrm{~F}$ & $20-30$ & Wildlife Vet & $\begin{array}{c}\text { B.S. Biological science, D.V.M. } \\
\text { degree }\end{array}$ & Americas & $\begin{array}{l}\text { Asian and } \\
\text { African }\end{array}$ & $\begin{array}{l}\text { Semi-captive, } \\
\text { Captive }\end{array}$ & Trained \\
\hline 4 & M & $40-50$ & $\begin{array}{l}\text { Vet, Elephant Supervisor and } \\
\text { chief of animal behavioral } \\
\text { Management, training } \\
\text { consultant }\end{array}$ & D.V.M. degree & Americas & $\begin{array}{l}\text { Asian and } \\
\text { African }\end{array}$ & $\begin{array}{l}\text { Semi-captive, } \\
\text { Captive }\end{array}$ & $\begin{array}{l}\text { Both trained } \\
\text { and untrained }\end{array}$ \\
\hline 5 & $\mathrm{~F}$ & Over 50 & Advocacy & Juris Doctor & Americas & - & Captive & Not answered \\
\hline 6 & M & $30-40$ & Animal Welfare Consultant & MS, PhD & Americas & $\begin{array}{l}\text { Asian and } \\
\text { African }\end{array}$ & $\begin{array}{l}\text { Semi-captive, } \\
\text { Captive }\end{array}$ & $\begin{array}{l}\text { Both trained } \\
\text { and untrained }\end{array}$ \\
\hline 7 & $\mathrm{~F}$ & Over 50 & $\begin{array}{l}\text { Wildlife Vet, university } \\
\text { researcher }\end{array}$ & DVM, MS, MPH, PhD & Americas & $\begin{array}{l}\text { Asian and } \\
\text { African }\end{array}$ & Wild, Captive & $\begin{array}{l}\text { Both trained } \\
\text { and untrained }\end{array}$ \\
\hline 8 & M & Over 50 & Animal Scientist & $\begin{array}{c}\text { BSc(Agric) Animal } \\
\text { Production; BSc Hons Agric } \\
\text { (Physiology); MSc (Agric) } \\
\text { Reproductive physiology }\end{array}$ & Africa & African & $\begin{array}{l}\text { Semi-captive, } \\
\text { Captive }\end{array}$ & $\begin{array}{l}\text { Both trained } \\
\text { and untrained }\end{array}$ \\
\hline 9 & M & $40-50$ & Owner/head Keeper & - & Europe & $\begin{array}{l}\text { Asian and } \\
\text { African }\end{array}$ & Captive & $\begin{array}{l}\text { Both trained } \\
\text { and untrained }\end{array}$ \\
\hline 10 & M & $40-50$ & Scientific consultant & Masters & Americas & & Wild, Captive & $\begin{array}{l}\text { Both trained } \\
\text { and untrained }\end{array}$ \\
\hline 11 & $\mathrm{~F}$ & - & $\begin{array}{l}\text { Zookeeper/Elephant care } \\
\text { specialist }\end{array}$ & Master & - & - & [Captive] - & - \\
\hline 12 & $\mathrm{~F}$ & Over 50 & $\begin{array}{l}\text { Director of Science, Research } \\
\text { and Advocacy }\end{array}$ & $\begin{array}{c}\text { Master of Science, } \\
\text { Anthrozoology, Canisius } \\
\text { College }\end{array}$ & Americas & $\begin{array}{l}\text { Asian and } \\
\text { African }\end{array}$ & Captive & Trained \\
\hline
\end{tabular}




\section{References}

1. Wittemyer, G.; Douglas-Hamilton, I.; Getz, W.M. The socioecology of elephants: Analysis of the processes creating multitiered social structures. Anim. Behav. 2005, 69, 1357-1371. [CrossRef]

2. Schulte, B.A. Behavior and social life. In Biology, Medicine, and Surgery of Elephants, 1st ed.; Fowler, M.E., Mikota, S.K., Eds.; Blackwell Publishing Ltd.: Ames, IA, USA, 2006; pp. 35-44.

3. Manteca, X. Elephants. In Zoo Animal Welfare. Giraffes and Elephants, 1st ed.; Manteca, X., Ed.; Mutimédica Ediciones Veterinarias: Sant Cugat del Vallés, Spain, 2016; pp. 39-80.

4. Byrne, R.W.; Bates, L.; Moss, C.J. Elephant cognition in primate perspective. Comp. Cogn. Behav. Rev. 2009, 4, 65-79. [CrossRef]

5. Bates, L.A.; Poole, J.H.; Byrne, R.W. Elephant cognition. Curr. Biol. 2008, 18, R544-R546. [CrossRef] [PubMed]

6. Hart, B.L.; Hart, L.A.; Pinter-Wollman, N. Large brains and cognition: Where do elephants fit in? Neurosci. Biobehav. Rev. 2008, 32, 86-98. [CrossRef] [PubMed]

7. Lee, P.C.; Moss, C.J. The social context for learning and behavioral development among wild African elephants. In Mammalian Social Learning: Comparative and Ecological Perspectives, 1st ed.; Box, H.O., Gibson, K.R., Eds.; Cambridge University Press: Cambridge, UK, 1999; pp. 102-125.

8. Plotnik, J.M.; de Waal, F.B.M.; Moore, D., III; Reiss, D. Self-Recognition in the Asian elephant and future directions for cognitive research with elephants in zoological settings. Zoo Biol. 2010, 29, 179-191. [CrossRef]

9. Manteca, X. (Ed.) Animal welfare: Concept and importance. In Zoo Animal Welfare. Concept and Indicators, 1st ed.; Multimédica Ediciones Veterinarias: Sant Cugat del Vallés, Barcelona, Spain, 2015; pp. 1-25.

10. Maple, T.L. Toward a science of welfare for animals in the zoo. J. Appl. Anim. Welf. Sci. 2007, 10, 63-70. [CrossRef]

11. Mason, G.J.; Veasey, J.S. How should the psychological well-being of zoo elephants be objectively investigated? Zoo Biol. 2010, 29, 237-255. [CrossRef]

12. Mason, G.J.; Veasey, J.S. What do population-level welfare indices suggest about the well-being of zoo elephants? Zoo Biol. 2010, 29, 256-273. [CrossRef]

13. Hosey, G.R. How does the zoo environment affect the behaviour of captive primates? Appl. Anim. Behav. Sci. 2005, 90, 107-129. [CrossRef]

14. Williams, E.; Chadwick, C.L.; Yon, L.; Asher, L. A review of current indicators of welfare in captive elephants (Loxodonta africana and Elephas maximus). Anim. Welf. 2018, 27, 235-249. [CrossRef]

15. Tannenbaum, J. Ethics and animal welfare: The inextricable connection. J. Am. Vet. Med. Assoc. 1991, 198, 1360-1376. [PubMed]

16. Fraser, D. Understanding Animal Welfare: The Science in Its Cultural Context; Fraser, D., Ed.; Wiley-Blackwell (UFAW): Ames, IA, USA, 2008.

17. Fraser, D.; Weary, D.M.; Pajor, E.A.; Milligan, B.N. A scientific conception of animal welfare that reflects ethical concerns. Anim. Welf. 1997, 6, 187-205.

18. Sandøe, P.; Simonsen, H.B. Assessing animal welfare: Where does science end and philosophy begin? Anim. Welf. 1992, 1, 257-267.

19. Rushen, J.; de Passillé, A.M.B. The scientific assessment of the impact of housing on animal welfare: A critical review. Can. J. Anim. Sci. 1992, 72, 721-743. [CrossRef]

20. Farm Animal Welfare Council. Farm Animal Welfare in Great Britain: Past, Present and Future; Farm Animal Welfare Council: London, UK, 2009. Available online: https:/assets.publishing.service.gov.uk/government/ uploads/system/uploads/attachment_data/file/319292/Farm_Animal_Welfare_in_Great_Britain_-_Past_ _Present_and_Future.pdf (accessed on 18 January 2019).

21. de Mori, B.; Ferrante, L.; Florio, D.; Macchi, E.; Pollastri, I.; Normando, S. A protocol for the ethical assessment of wild Animal-Visitor Interactions (AVIP) evaluating animal welfare, education, and conservation outcomes. Animals 2019, 9, 487. [CrossRef]

22. Schmidt-Burbach, J.; Ronfot, D.; Srisangiam, R. Asian elephant (Elephas maximus), pig-tailed macaque (Macaca nemestrina) and tiger (Panthera tigris) populations at tourism venues in Thailand and aspects of their welfare. PLoS ONE 2015, 10, e0139092. [CrossRef]

23. Ramsay, K.A.; Department of Agriculture Forestry and Fisheries, South Africa-Former Scientific Manager, Animal Production. Personal Communication, 2016. 
24. National Norms and Standards for the Management of Elephants in South Africa, 2 November 2018, Section 9(1) of the National Environmental Management: Biodiversity Act, 2004 (ACT No:10 of 2004). Department of Environmental Affairs and Tourism. Available online: https://www.environment.gov.za/sites/default/files/gazetted_notices/nemba10of2004_ nationalnormsandstandards_managementofelephants_gn42015.pdf (accessed on 24 August 2019).

25. Rossman, Z.T.; Padfield, C.; Young, D.; Hart, L.A. Elephant-initiated interactions with humans: Individual differences and specific preferences in captive African elephants (Loxodonta africana). Front. Vet. Sci. 2017, 4, 60. [CrossRef]

26. Kreger, M.D.; Mench, J.A. Visitor-Animal interactions at the zoo. Anthrozoös 1995, 8, 143-158. [CrossRef]

27. Laule, G.; Whittaker, M. Protected contact and elephant welfare. In An Elephant in the Room: The Science and Well-Being of Elephants in Captivity; Tufts Centre for Animals and Public Policy: North Grafton, MA, USA, 2009; pp. 181-188. Available online: https://www.researchgate.net/profile/Margaret_Whittaker2/publication/ 265265873_Protected_Contact_and_Elephant_Welfare/links/54e5f0e10cf277664ff1b6e6/Protected-Contactand-Elephant-Welfare.pdf (accessed on 24 August 2019).

28. Graham, C.; von Keyserlingk, M.A.G.; Franks, B. Free-choice exploration increases affiliative behaviour in zebrafish. Appl. Anim. Behav. Sci. 2018, 203, 103-110. [CrossRef]

29. Clubb, R.; Mason, G. A Review of the Welfare of Zoo Elephants in Europe; RSPCA: Horsham, UK, 2002.

30. Hemsworth, P.H.; Barnett, J.L.; Beveridge, L.; Matthews, L.R. The welfare of extensively managed dairy cattle: A review. Appl. Anim. Behav. Sci. 1995, 42, 161-182. [CrossRef]

31. Kurt, F. The preservation of Asian elephants in human care-A comparison between the different keeping systems in South Asia and Europe. Anim. Res. Dev. 1995, 41, 38-60.

32. Krishnamurthy, V. Reproductive pattern in captive elephants in the Tamil Nadu Forest Department: India. In A Week with Elephants, Proceedings of the International Seminar on the Conservation of Asian Elephants, Mudumalai Wildlife Sanctuary, India, 13-18 June 1993; Daniel, J.C., Datye, H.S., Eds.; Oxford University Press: Bombay, India, 1995; pp. 450-455.

33. Harris, M.; Sherwin, C.; Harris, S. The Welfare, Housing and Husbandry of Elephants in UK Zoos; University of Bristol: Bristol, UK, 2008.

34. Martin, P.; Bateson, P. Measuring Behavior-An Introductory Guide, 3rd ed.; Cambridge University Press: Cambridge, UK, 2007.

35. Mason, G.; Mendl, M. Why is there no simple way of measuring animal welfare? Anim. Welf. 1993, 2, 301-319.

36. Lehner, P. Handbook of Ethological Methods, 2nd ed.; Cambridge University Press: Cambridge, UK, 1996.

37. Taylor, K.D.; Mills, D.S. The development and assessment of temperament tests for adult companion dogs. J. Vet. Behav. Clin. Appl. Res. 2006, 1, 94-108. [CrossRef]

38. Clubb, R.; Rowcliffe, M.; Lee, P.; Mar, K.U.; Moss, C.; Mason, G.J. Compromised survivorship in zoo elephants. Science 2008, 322, 1649. [CrossRef] [PubMed]

39. Kreger, M.D.; Hutchins, M. Ethics of keeping mammals in zoos and aquariums. In Wild Mammals in Captivity: Principles \& Techniques for Zoo Management, 2nd ed.; Kleiman, D., Thompson, K.V., Baer, C.K., Eds.; University of Chicago Press: Chicago, IL, USA, 2010; pp. 3-10.

40. Carlstead, K.; Mench, J.A.; Meehan, C.; Brown, J.L. An epidemiological approach to welfare research in zoos: The elephant welfare project. J. Appl. Anim. Welf. Sci. 2013, 16, 319-337. [CrossRef] [PubMed]

41. Greco, B.J.; Meehan, C.L.; Hogan, J.N.; Leightly, K.A.; Mellen, J.; Mason, G.J.; Mench, J.A. The days and nights of zoo elephants: Using epidemiology to better understand stereotypic behavior of African elephants (Loxodonta africana) and Asian elephants (Elephas maximus) in North American zoos. PLoS ONE 2016, 11, e0144276. [CrossRef]

42. Holdgate, M.R.; Meehan, C.L.; Hogan, J.N.; Miller, L.J.; Soltis, J.; Andrews, J.; Shepherdson, D.J. Walking behavior of zoo elephants: Associations between GPS-measured daily walking distances and environmental factors, social factors, and welfare indicators. PLoS ONE 2016, 11, e0150331. [CrossRef]

43. Holdgate, M.R.; Meehan, C.L.; Hogan, J.N.; Miller, L.J.; Rushen, J.; de Passillé, A.M.; Soltis, J.; Andrews, J.; Shepherdson, D.J. Recumbence behavior in zoo elephants: Determination of patterns and frequency of recumbent rest and associated environmental and social factors. PLoS ONE 2016, 11, e0153301. [CrossRef] 
44. Brown, J.L.; Paris, S.; Prado-Oviedo, N.A.; Meehan, C.L.; Hogan, J.N.; Morfeld, K.A.; Carlstead, K. Reproductive health assessment of female elephants in North American zoos and association of husbandry practices with reproductive dysfunction in African elephants (Loxodonta africana). PLoS ONE 2016, 11, e0145673. [CrossRef]

45. Miller, M.A.; Hogan, J.N.; Meehan, C.L. Housing and demographic risk factors impacting foot and musculoskeletal health in African elephants (Loxodonta africana) and Asian elephants (Elephas maximus) in North American zoos. PLoS ONE 2016, 11, e0155223. [CrossRef]

46. Morfeld, K.A.; Meehan, C.L.; Hogan, J.N.; Brown, J.L. Assessment of body condition in African (Loxodonta africana) and Asian (Elephas maximus) elephants in North American zoos and management practices associated with high body condition scores. PLoS ONE 2016, 11, e0155146. [CrossRef] [PubMed]

47. Prado-Oviedo, N.A.; Bonaparte-Saller, M.K.; Malloy, E.J.; Meehan, C.L.; Mench, J.A.; Carlstead, K.; Brown, J.L. Evaluation of demographics and social life events of Asian (Elephas maximus) and African elephants (Loxodonta africana) in North American zoos. PLoS ONE 2016, 11, e0154750. [CrossRef] [PubMed]

48. Greco, B.J.; Meehan, C.L.; Heinsius, J.L.; Mench, J.A. Why pace? The influence of social, housing, management, life history, and demographic characteristics on locomotor stereotypy in zoo elephants. Appl. Anim. Behav. Sci. 2017, 194, 104-111. [CrossRef]

49. Greco, B.J.; Meehan, C.L.; Miller, L.J.; Shepherdson, D.J.; Morfeld, K.A.; Andrews, J.; Baker, A.M.; Carlstead, K.; Mench, J.A. Elephant management in North American zoos: Environmental enrichment, feeding, exercise, and training. PLoS ONE 2016, 11, e0152490. [CrossRef] [PubMed]

50. Meehan, C.L.; Mench, J.A.; Carlstead, K.; Hogan, J.N. Determining connections between the daily lives of zoo elephants and their welfare: An epidemiological approach. PLoS ONE 2016, 11, e0158124. [CrossRef]

51. Meehan, C.L.; Hogan, J.N.; Bonaparte-Saller, M.K.; Mench, J.A. Housing and social environments of African (Loxodonta africana) and Asian (Elephas maximus) elephants in North American zoos. PLoS ONE 2016, 11, e0146703. [CrossRef]

52. Asher, L.; Williams, E.; Yon, L. Developing Behavioural Indicators, as Part of a Wider Set of Indicators, to Assess the Welfare of Elephants in UK Zoos; Defra: Bristol, UK, 2015.

53. Yon, L.; Williams, E.; Harvey, N.D.; Asher, L. Development of a behavioural welfare assessment tool for routine use with captive elephants. PLoS ONE 2019, 14, e0210783. [CrossRef]

54. de Mori, B.; Normando, S.; Vogt, G.; Stagni, E.; Fazio, G.; Avesani, C.; Patarnello, T.; Martini, M.; Rehse, T.; Kotze, A. South African elephants' welfare index and conservation education. In Proceedings of the 69th World Association of Zoos and Aquariums (WAZA) Annual Conference and Technical Congress, New Delhi, India, 2-6 November 2014.

55. Normando, S.; Stagni, E.; Sergi, V.; Bettin, E.; Sgarbossa, A.; Mazzola, A.; Bordignon, F.; Kotze, A.; Vogt, G.; Ramsay, K.A.; et al. Are semi-captive African elephants different from their zoo counterparts? In Proceedings of the IX Convegno Nazionale della Ricerca nei Parchi, Parco Natura Viva, Bussolengo (VR), Italy, 4-7 October 2018.

56. Normando, S.; Pollastri, I.; Florio, D.; Ferrante, L.; Macchi, E.; Isaja, V.; de Mori, B. Assessing animal welfare in animal-visitor interactions in zoos and other facilities. A pilot study involving giraffes. Animals 2018, 8 , 153. [CrossRef]

57. Harding, E.J.; Paul, E.S.; Mendl, M. Cognitive bias and affective state. Nature 2004, 427, 312. [CrossRef]

58. Gurusamy, V.; Tribe, A.; Phillips, C. Identification of major welfare issues for captive elephant husbandry by stakeholders. Anim. Welf. 2014, 23, 11-24. [CrossRef]

59. Chadwick, C.; Williams, E.; Asher, L.; Yon, L. Incorporating stakeholder perspectives into the assessment and provision of captive elephant welfare. Anim. Welf. 2017, 26, 461-472. [CrossRef]

60. Whay, H.R.; Main, D.C.J.; Greent, L.E.; Webster, A.J.F. Animal-based measures for the assessment of welfare state of dairy cattle, pigs and laying hens: Consensus of expert opinion. Anim. Welf. 2003, 12, 205-217.

61. Phythian, C.J.; Michalopoulou, E.; Jones, P.H.; Winter, A.C.; Clarkson, M.J.; Stubbings, L.A.; Grove-White, D.; Cripps, P.J.; Duncan, J.S. Validating indicators of sheep welfare through a consensus of expert opinion. Animal 2011, 5, 943-952. [CrossRef] [PubMed]

62. Millar, K.; Thorstensen, E.; Tomkins, S.; Mepham, B.; Kaiser, M. Developing the ethical Delphi. J. Agric. Environ. Ethics 2007, 20, 53-63. [CrossRef]

63. Young, T.; Creighton, E.; Smith, T.; Hosie, C. A novel scale of behavioural indicators of stress for use with domestic horses. Appl. Anim. Behav. Sci. 2012, 140, 33-43. [CrossRef] 
64. Clegg, I.L.K.; Rödel, H.G.; Boivin, X.; Delfour, F. Looking forward to interacting with their caretakers: dolphins' anticipatory behaviour indicates motivation to participate in specific events. Appl. Anim. Behav. Sci. 2018, 202, 85-93. [CrossRef]

65. de Passillé, A.M.; Rushen, J. Can we measure human-animal interactions in on-farm animal welfare assessment? Some unresolved issues. Appl. Anim. Behav. Sci. 2005, 92, 193-209. [CrossRef]

66. Pritchard, J.C.; Lindberg, A.C.; Main, D.C.J.; Whay, H.R. Assessment of the welfare of working horses, mules and donkeys, using health and behaviour parameters. Prev. Vet. Med. 2005, 69, 265-283. [CrossRef]

67. Web of Science. Available online: http://wokinfo.com/ (accessed on 15 July 2019).

68. Hernández, A.; König, S.E.; Zúñiga, J.J.R.; Galina, C.S.; Berg, C.; Gonzales, M.R.; Villalobos, A.D. Implementation of the Welfare Quality ${ }^{\circledR}$ protocol in dairy farms raised on extensive, semi-intensive and intensive systems in Costa Rica. J. Anim. Behav. Biometeorol. 2017, 5, 132-138. [CrossRef]

69. Hernandez, A.; Berg, C.; Eriksson, S.; Edstam, L.; Orihuela, A.; Leon, H.; Galina, C. The Welfare Quality ${ }^{\circledR}$ assessment protocol: How can it be adapted to family farming dual purpose cattle raised under extensive systems in tropical conditions? Anim. Welf. 2017, 26, 177-184. [CrossRef]

70. Scott, E.M.; Nolan, A.M.; Reid, J.; Wiseman-Orr, M.L. Can we really measure animal quality of life? Methodologies for measuring quality of life in people and other animals. Anim. Welf. 2007, 16, 17-24.

71. Vas, J.; Topál, J.; Péch, É.; Miklósi, Á. Measuring attention deficit and activity in dogs: A new application and validation of a human ADHD questionnaire. Appl. Anim. Behav. Sci. 2007, 103, 105-117. [CrossRef]

72. Rayment, D.J.; de Groef, B.; Peters, R.A.; Marston, L.C. Applied personality assessment in domestic dogs: Limitations and caveats. Appl. Anim. Behav. Sci. 2015, 163, 1-18. [CrossRef]

73. Richter, S.H.; Garner, J.P.; Würbel, H. Environmental standardization: Cure or cause of poor reproducibility in animal experiments? Nat. Methods 2009, 6, 257-261. [CrossRef] [PubMed]

74. Tipton, E.; Peck, L.R. A design-based approach to improve external validity in welfare policy evaluations. Eval. Rev. 2017, 41, 326-356. [CrossRef] [PubMed]

75. Bettin, E. Utilizzo dell'Expert Consensus e dell'Ethical Delphi per la Valutazione delle Condizioni di Benessere dell'Elefante Africano (Loxodonta africana) in Cattività e Semi-Cattività. DVM Thesis, University of Padua, Padua, Italy, 22 September 2016. [Use of Expert Consensus and Ethical Delphi to Assess the Welfare of Captive and Semi-Captive African Elephants (Loxodonta africana)]. Under the Supervision of Normando, S. and de Mori, B. Available online: http://tesi.cab.unipd.it/57432/1/Bettin\%2C_Elisa.pdf (accessed on 24 September 2019).

76. Handler killed by Elephant at Victoria Falls. Available online: https://www.iol.co.za/news/africa/handlerkilled-by-elephant-at-victoria-falls-10471019 (accessed on 24 August 2019).

77. Gore, M.; Hutchins, M.; Ray, J. A review of injuries caused by elephants in captivity: An examination of predominant factors. Int. Zoo Yearb. 2006, 40, 51-62. [CrossRef]

78. AZA Standards for Elephant Management and Care. 2011. Available online: https://www.speakcdn.com/ assets/2332/aza_standards_for_elephant_management_and_care.pdf (accessed on 24 August 2019).

79. Wilson, M.L.; Perdue, B.M.; Bloomsmith, M.A.; Maple, T.L. Rates of reinforcement and measures of compliance in free and protected contact elephant management systems. Zoo Biol. 2015, 34, 431-437. [CrossRef]

80. Csuti, B. Elephants in captivity. In Biology, Medicine and Surgery of Elephants, 1st ed.; Fowler, M.E., Mikota, S.K., Eds.; Blackwell Publishing Ltd.: Ames, IA, USA, 2006; pp. 15-22.

81. Turner, S.P.; Dwyer, C.M. Welfare assessment in extensive animal production systems: Challenges and opportunities. Anim. Welf. 2007, 16, 189-192.

(C) 2019 by the authors. Licensee MDPI, Basel, Switzerland. This article is an open access article distributed under the terms and conditions of the Creative Commons Attribution (CC BY) license (http://creativecommons.org/licenses/by/4.0/). 